Article

\title{
An Economic Evaluation of the use of Wind Farms in Iran, Tak- ing into Account the Effect of Energy Price Liberalization Policy
}

\author{
Nima Norouzi, Zahra Bashashjafarabadi, Seyyed Mohammad Yahya Meybodi * \\ Department of energy engineering and physics, Amirkabir university of technology (Tehran polytechnic), 424 \\ Hafez Avenue, PO Box 15875-4413, Tehran, Iran \\ *Correspondence: nima1376@aut.ac.ir.
}

How to cite this paper: Norouzi, N., Bashashjafarabadi, Z., \& Meybodi, S. M. Y. (2021). An Economic Evaluation of the use of Wind Farms in Iran, Taking into Account the Effect of Energy Price Liberalization Policy. Universal Journal of Business and Management, 1(1), 49-61. Retrieved from https://www.scipublications.com/journal/index.php/ujbm/article/view/76

Received: July 7, 2021

Accepted: August 13, 2021

Published: August 14, 2021

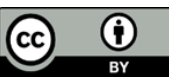

Copyright: (C) 2021 by the authors. Submitted for possible open access publication under the terms and conditions of the Creative Commons Attribution (CC BY) license (http://creativecommons.org/licenses /by/4.0/).

\begin{abstract}
In this study, the effect of energy cost liberalization policies on the cost-effectiveness of wind farms compared to gas power plants has been investigated. To calculate the cost of electricity generation from various sources, including wind energy and fossil fuels, the "levelized cost" method has been used as the most acceptable economic method to compare different types of electricity generation technologies. In addition, calculations related to the cost of electricity, different fuel prices, different technologies of wind farms, and different prices of different types of fuel are considered. Based on the results of this research, it was found that by targeting fuel prices in the country, wind farms are quite cost-effective, and considering the cost of the opportunity to use diesel in the country, the construction of these power plants can provide the possibility of exporting this fuel. This cost also increases with the production of valuable equipment in the country. The important point is that the macro policy should localize the wind turbine industry with priority to its valuable parts and components due to fuel price changes. This policy will continue to make this type of power plant cost-effective in the country and the employment of specialists in the country.
\end{abstract}

Keywords: wind farm; gas power plant; energy price liberalization; levelized cost.

\section{Introduction}

The importance of energy in today's world has led various countries to develop energy resources, oil, coal, and gas - which are the most common and polluting energy sources globally - increase the share of new renewable sources in their energy portfolio. Among the various types of renewable energy, wind energy is more than other renewable sources in the world.

Iran is a large country with many windy places. These resources can meet many of the country's energy needs in the not too distant future. Unfortunately, in recent years, little attention has been paid to this issue. This is because oil and gas prices in Iran are unrealistic, and therefore, wind energy has lost its economic justification[1, 2].

With the liberalization of prices and the realization of the price of diesel and gas in Iran, electricity production using wind energy is competitive with other energy sources. This research seeks to show that it is scientifically possible to justify energy production through wind compared to energy production through fossil fuels (gas power plants) by considering the actual fuel price without subsidies. For this purpose, we provide a scientific approach to this issue and examine various issues. Due to the importance of wind energy for sustainable energy supply in the country, we first examine the importance of paying attention to this area and then express the important hypotheses raised in this research. The research method and research results are presented below $[3,4]$. 


\section{Literature Review}

This article seeks to examine the cost of generating electricity from wind farms and compare it with the actual cost of generating electricity using fossil fuels. For this purpose, we review the activities carried out in this field over the past years.

Due to the importance of this issue, many studies have been conducted to compare the cost of electricity generation from different sources. In many studies, wind power generation costs have been compared with other power generation methods, some of which are mentioned below. In some of these studies, due to the differences in electricity generation technologies in terms of investment requirements and maintenance specifications, to achieve a correct and scientific comparison, the costs are transferred to the base year using the discount rate and, in this case, levelized cost. Levelized costs include investment or initial costs, maintenance costs, fuel costs, and external impact costs. Maintenance costs themselves are divided into two parts, fixed and variable. Fixed costs are proportional to the installed capacity, and variable costs depend on the level of production.

A researcher compared three types of energy production methods. These methods include energy production through algal biodiesels, canola biodiesels, and fossil fuels. By analyzing private costs for energy production, they have shown that algal biodiesel, the second generation of biodiesel generators, has no economic advantage over other methods. Of course, certain conditions under which algal biodiesels can compete with other methods[1].

Another study has done a useful life analysis for electricity generated by conventional and renewable systems in Egypt using the LCC model. In his analysis, he considers the cost of externalities based on the competitive locations of solar cells and wind energy converters. His research shows that the costs of conventional systems increase over time due to reduced resources and the strengthening of environmental pollution standards. According to this research, wind energy is the most economical energy, but it should be noted that wind is not always present to achieve accurate results[2].

Another researcher, by statistically examining the production of various energy sources, has shown that wind farms compete with power plants due to the increase in investment costs in energy production, increase in fossil fuel prices over time, and increase in the tendency to calculate environmental costs and profits. It is common to generate electricity[3].

Other researchers compared fourteen different technologies using the levelized cost method. Specifically, the addition of the cost of external effects in finding the final costs has been studied in this work. The result of the research is that increasing the cost of external influences increases freedom of choice. Clean energy is also cost-effective[4].

Data published by a researcher shows that wind power at the cost of $\$ 48$ to $\$ 95$ per megawatt-hour is one of the cheapest power generation options that all of these calculations have been done for the United States[5].

In 2010, the NEA and EIA examined the equilibrium cost of power generation technologies in different countries (Figure 1). These reports show many differences between different countries regarding the change in construction costs and electricity production costs. According to these reports, the main part of electricity generation costs in non-fossil power plants is investment costs, while more than half of the final cost of fossil electricity is fuel costs.

Therefore, if the costs of external influences such as air pollution in the region and the emission of greenhouse gases are properly calculated, the total cost of electricity generation will change and increase. 


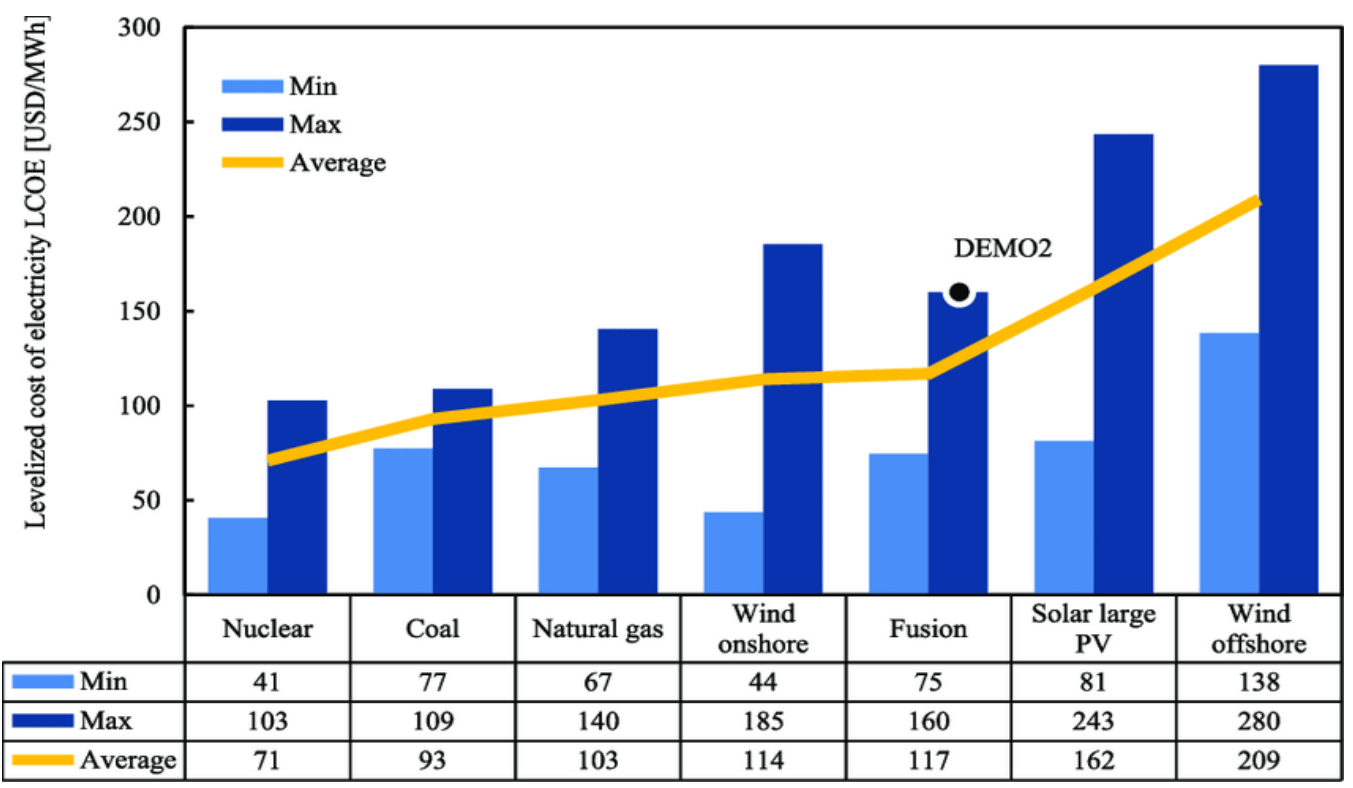

Figure 1. Cost of different power generation options(Entler et al., 2018)

The study of internal studies in the field of wind power plant development shows that the orientation of most of these studies is towards the economic and technical study of wind power plant construction. Research has studied wind power technologies, their electronic control, and production quality control of production power. In this research, after examining wind power plants from a technical and financial perspective, the price of electricity produced by these units has been calculated. By calculating the present value of electricity generated from wind, steam, and gas power plants and taking into account the social cost of three important environmental pollutants (carbon dioxide, sulfur dioxide, and nitrogen oxides), wind power plants are more economical than conventional power plants with conditions Compared has been achieved. Also, a case study of turbines installed in Manjil and Rudbar has shown that the annual production of turbines in these two sites is more than the annual production of similar turbines in other parts of the world[6]. Another researcher has performed a financial and economic evaluation of wind power plants using Excel and Visual Basic software based on the economic indicators of profit to cost and net present value of capital[8]. An expert compared wind power plants with competing options such as gas and hydropower plants and combined cycle. In this research, based on the cost-equalized cost method, the electricity produced in these power plants has been compared with each other, and different scenarios of fuel price (natural gas fuel) with a fixed fuel price have been developed [9]. In another study, the various effects of wind and fossil power plant were calculated numerically and included them in the production cost. In another paper, during a study, I have studied the various wind turbines available in the global market for use in the teachers' area of Semnan province from an economic point of view and have selected two types of turbines as the best option[10]. Other researchers, using the MIRR method from the perspective of shareholders and private sector partners, have evaluated the economic use of wind energy. They have shown that by considering the price of fossil fuels and the sale of electricity at world prices on the energy exchange and assuming the sale of CER securities, the plan is economically justified from shareholders and trading partners with low borrowing rates and high reinvestment rates[11]. Another researcher has studied successful countries in wind power generation to provide a suitable support solution for wind power development [12].

Studies conducted in reputable domestic databases such as the Iranian Institute of Science and Technology and the National Library showed that price liberalization in various fields such as agricultural products and the automotive industry had been studied. 
However, in energy cost liberalization policies on renewable energy development, especially wind energy, no research has been done that has studied different dimensions[13, 14].

Although many studies have been conducted on the economics of wind power generation, so far, a study that includes a sensitivity analysis of fuel prices (given the country's economic conditions and fluctuating fuel prices, this is particularly important) to examine the effects of liberalization of energy prices has not been done with two types of gas and diesel fuels, as well as considering different technologies for wind power generation. Given the need to liberalize energy prices in the country to increase productivity, reduce the intensity of energy consumption in the country, and equitable distribution of energy subsidies, it is necessary to examine various aspects of the effectiveness of this policy in the development of wind farms. The results of this research will help researchers, policymakers, and executives of the country's energy sector to gain more knowledge of the effects of these policies and, as a result, if necessary, to review and amend existing policies. For this research, two hypotheses are defined as follows: 1. Energy price liberalization has positive effects on wind energy use. 2. Energy price liberalization policies lead to more cost-effective wind energy than conventional (gas) power plants.

\section{Materials and Methods}

The net present value method is one of the discount indicators of the project's value and evaluates a project using the net present value of its benefits. First, all revenues and expenses must be converted to present value, and the net present value of benefits can be obtained from the difference between revenues and expenses. If the NPV is less than zero, it is a non-economic project, but if the NPV is positive, it is an economic project, and it means that the current value of expenses is less than the current value of revenues (Skonjad, Mohammad Mehdi, 2009).

$$
N P V(i, N)=\sum_{t=0}^{N} \frac{R_{t}}{(1+i)^{t}}
$$

t: cash flow period i: interest rate Rt: net cash flow

The internal rate of return method is the rate at which the project's net present value is zero. To calculate this rate, the above relation is set to zero. The rate (number i) obtained from solving this equation is the rate of internal efficiency of the project (Majidian, Davood, 2003). A levelized cost method or uniform annual cost approach is similar to the current value method. In this way, costs are converted into a uniform annual payment. In other words, cost equals a fixed amount of revenue per unit of product that can cover all project costs over the life of the service. The internal rate of return method and the present value method only examine the profitability of projects and increase the initial investment value. While from the government's point of view, investments are generally made at lower costs. In other words, for the government, a power plant where the cost of producing a unit of electricity is lower is a priority. As a result, indicators such as profitability and the net present value of the investment are the next indicators to evaluate.

In explaining this issue, it can be added that the internal rate of return method is used in financial analysis and the decision to enter or not to invest in the project and does not talk about the cost; As this method determines the rate of return that the investor is willing to invest in the project. Since this study aims to obtain the cost of power plant electricity from the government's point of view, it is not appropriate to use the internal rate of return method to address this issue. Also, in the present value model, to compare the projects, the common life of the projects should be considered. Due to the variable lifespan of gas and wind power plants, therefore, economic evaluation of the cost of electricity of these power plants, which have different life cycles, is not appropriate to use this method and therefore we abandon it, so according to these conditions, the Levelized method cost has 
been used as the method used in the economic analysis of power plant projects. In this method, the project cost is calculated using annual costs over the plant's life cycle and includes initial costs (design, certification, installation), operating costs, maintenance costs, and external costs. Discount rates are usually used to calculate the present value of costs, expressed as a percentage and annually. Costs are divided into electricity generation costs and costs imposed on the community during electricity generation. Electricity generation costs include variables such as initial investment, maintenance costs, and fuel costs. Since maintenance costs and fuel costs increase with inflation and rising fuel prices, respectively, their growth rate can be included in the calculations. Maintenance costs are classified into two categories: fixed and variable. In the second part, the equalized cost of electricity generation is the cost imposed on society, which includes the costs of external effects of electricity generation. For example, the cost of damage caused by the emission of pollutants by fossil fuel power plants significantly affects the equivalent cost of electricity generation of these power plants but does not affect the electricity generation of wind farms. Considering these factors, the final equation of electricity generation cost can be written as follows.

$$
\begin{gathered}
\text { LCOE }=C_{k}+\left[\sum_{t=0}^{P L} \frac{C_{O \& M}\left(1+e_{O \& M}\right)^{t}}{(1+r)^{t}}+\sum_{t=0}^{P L}\left(\frac{C_{f u e l}\left(1+e_{f u e l}\right)^{t}}{(1+r)^{t}}\right)\right] \\
\times \frac{r(1+r)^{p l}}{(1+r)^{p l}-1}+C_{E C}
\end{gathered}
$$

According to this relationship, the costs have been transferred to the current year to calculate the present value of the project. Multiplying the present value of the maintenance cost and fuel cost variables by invoicing factor $\left(\frac{r(1+r)^{p l}}{(1+r)^{p l}-1}\right)$ makes them a uniform annual cost.

$$
\begin{aligned}
& C_{k}=\frac{D R \times T P C(1+r)^{C L}}{H Y \times C F} \\
& C_{O \& M}=\frac{F O M}{H Y \times C F}+V O M \\
& C_{f u e l}=F C \times H R \\
& C_{E C}=E F \times H R \times V E D
\end{aligned}
$$

In this regard, $\mathrm{CEc}$ represents the costs imposed on society (costs of external effects) by polluting gases such as $\mathrm{CO}_{2}, \mathrm{SO}_{2}$, and $\mathrm{NO}$. Pollution factor $\mathrm{EF}$ indicates the amount of pollution per unit of fuel energy consumption. HR is the heat rate of power plants, and VED represents the degree of environmental degradation. EF and HR are physical values that can be calculated, while VEDs can be calculated by directly estimating costs, reducing costs, or combining them. VED is an important parameter for regulatory analysis, but it is usually difficult to calculate. The cost of external effects per unit of electricity generated using these factors and their inclusion in the LCOE formula is calculated directly. As can be seen in the above relationships, the LCOE can be determined based on total capital costs, maintenance costs, fuel costs, and external impact costs. 
Table 1. Definition of the parameters of the levelized cost equation

\begin{tabular}{|c|c|c|}
\hline Variable & Unit of measurement & Name \\
\hline CK & $\$ / \mathrm{kWh}$ & Capital Cost \\
\hline DR & $\%$ & Depreciation Rate \\
\hline TPC & $\$ / \mathrm{kWh}$ & Total Plant Cost \\
\hline $\mathrm{CL}$ & Year & Construction Life \\
\hline $\mathrm{R}$ & $\%$ & Discount Rate \\
\hline HY & $\mathrm{hr}$ & Hours Per Year \\
\hline $\mathrm{CF}$ & Percentage & Capacity Factor \\
\hline $\mathrm{Co}_{\mathrm{C} M}$ & $\$ / \mathrm{kWh}$ & Total O\&M Cost \\
\hline EO\&M & $\%$ & Escalation Rate Of O\&M Cost \\
\hline FOM & $\$ / \mathrm{kWh}$ & Total Fixed O\&M Cost \\
\hline VOM & $\$ / \mathrm{kWh}$ & Total Variable O\&M Cost \\
\hline HR & BTU/KWH & Heat Rate \\
\hline PL & Year & Plant Life \\
\hline FC & $\$ / \mathrm{kWh}$ & Fule Cost \\
\hline EFUel & $\%$ & Escalation Rate Of Fuel Costs \\
\hline CEC & $\$ / \mathrm{kWh}$ & External Cost \\
\hline VED & $\$ / g r$ & Value Of Enviormental Damage \\
\hline $\mathrm{EF}$ & gr/BTU & Emission Factor \\
\hline LCOE & $\$ / \mathrm{kWh}$ & Levelized Cost Of Energy \\
\hline
\end{tabular}

The method used in this research is descriptive-analytical. In this study, using the descriptive-analytical method, different scenarios of implementing the law of liberalization of energy cost on the development of the use of wind energy in the country are investigated. This study's importance and usefulness are because based on which scenario, it will be determined which lower cost price for wind energy will be obtained compared to thermal (gas) power plants in the country and the price consequences of each scenario. It is necessary to explain that to implement different scenarios and ease the calculations related to the consequences of each scenario; excel software has been used.

To balance the scenarios presented in the previous section, the levelized cost method is used. In the cost-equalization method, a similar approach to the current value method is used. In this method, the costs are reduced to a uniform annual cost by discounting the base year. Figure 2 shows the variables that are considered to calculate the aligned cost.

In gas power plants, the share of fuel prices in the cost of energy is higher than in other power plants. On the other hand, the liberalization of energy costs in this study means the liberalization of fuel prices or energy carriers. Therefore, in the built model, gas power plants (as the holder of the largest share of fuel prices in energy prices and the share of electricity generation capacity compared to other power plants) are compared with the wind $[15,16]$. 


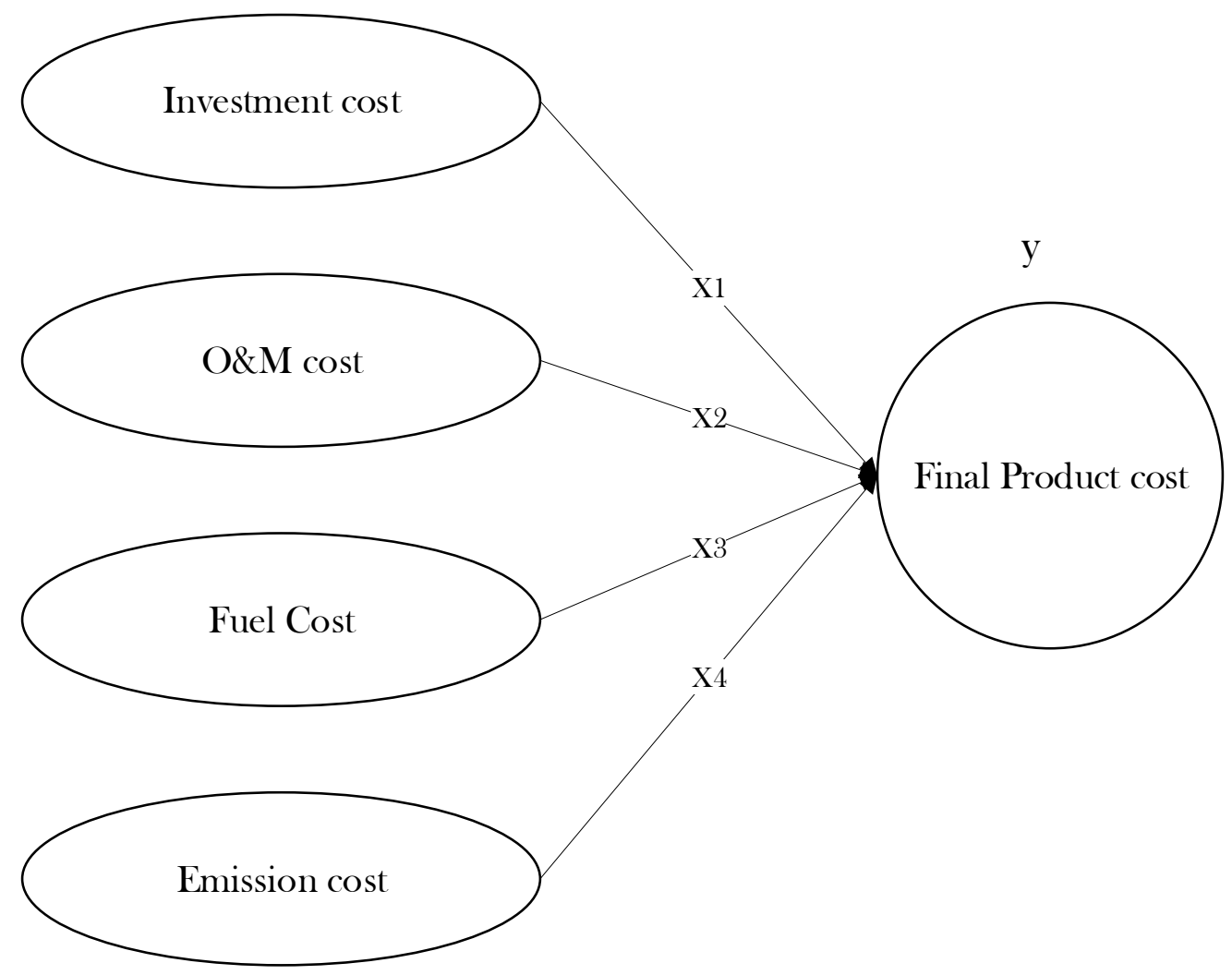

Figure 2. Conceptual model of variables

Finally, by comparing and analyzing the sensitivity of levelized energy costs in wind and gas power plants, we can examine the effect of energy cost liberalization policies on the development of wind power plants. In this study, we only examine the levelized cost from the investor's point of view. We consider the power plant's construction site one of the suitable sites introduced by the New Energy Organization of Iran (SANA). Also, exogenous factors such as distribution and transmission network conditions around the power plant are ignored. In addition to the different technologies of wind turbines selected in this research, two technologies are identified: first, $660 \mathrm{~kW}$ wind turbines that are produced in the country in Sabaniro company and second, 2 MW wind turbines, which were studied in Niroo Research Institute as Turbines suitable for installation in the country have been introduced. The capacity coefficient used for the wind power plant in this research is considered from SANA information and is appropriate to the average climatic conditions of the country. This coefficient for gas power plants is taken from detailed statistics of the electricity industry. The calculations are based on various information, the details of which are given in Table 2. The basis for collecting information in this table is the use of official statistics obtained from organizations including the Deputy of Production of Tavanir Company (Energy Balance), Wind Engineering Office of the New Energy Organization of Iran (SANA), National Oil Company, World Bank. In the current situation where subsidized fuel is allocated to power plants, power plants must pay seven hundred riyals per cubic meter of gas and three thousand five hundred riyals per liter of diesel. These prices are used in Table 2 and calculations. The discount rate is considered according to the country's general inflation rate and economic conditions in the past years and using field information from economic analysts. Other assumptions used in the calculations are based on 2011 statistics, which is the year of implementing the law on targeted subsidies. Also, this study has been done considering the conditions in which the geographical situation does not limit electricity production, and the wind turbine can operate at its maximum nominal capacity[17-24]. 
Table 2. Model input data for comparative study of gas power plant and wind power plant

\begin{tabular}{|c|c|c|c|c|}
\hline Parameter & Wind 2MW & Wind 660kW & Large scale gas & unit \\
\hline Total capacity (MW) & 100 & 100.32 & 100 & \\
\hline Number & 50 & 152 & 4 & \\
\hline Unit capacity (MW) & 2 & 0.66 & 25 & \\
\hline Model & Vestas - V90 & Vestas - V47 & & 36 \\
\hline Capacity factor (CF) & 35 & 26 & 15 & $\%$ \\
\hline Adjustment coefficient & 15 & 15 & 15 & $\%$ \\
\hline Fuel adjustment coefficient & - & - & 22.6229 & $\$ / \mathrm{Mbtu}$ \\
\hline Real fuel cost (FC) & - & - & 4.1 & $\$ / \mathrm{Mbtu}$ \\
\hline Fuel cost (FC) & - & - & 8.6457 & $\$ / \mathrm{Mbtu}$ \\
\hline Real gas cost (FC) & - & - & 0.81 & $\$ / \mathrm{Mbtu}$ \\
\hline Gas cost (FC) & - & - & 0.012 & $\mathrm{Mbtu} / \mathrm{kWh}$ \\
\hline Heat rate (HR) & - & - & 76969.5 & $\mathrm{Gr} / \mathrm{mbtu}$ \\
\hline Emission & - & - & 0.011 & $\$ / \mathrm{gr}$ \\
\hline Environmental cost (WED) & - & 0 & 7358.4 & $\mathrm{hr}$ \\
\hline Operating hours (HY) & 8497.2 & 8497.2 & - & $\$ / \mathrm{kWy}$ \\
\hline Fixed Maintenance Cost (FOM) & 30 & 30 & 0.1898018 & $\$ / \mathrm{kWh}$ \\
\hline Variable Maintenance Cost (VOM) & 0.8 & 0.8 & 1 & Year \\
\hline Construction time & 2 & 2 & 229.824 & $\$ / \mathrm{kW}$ \\
\hline Total initial cost of the plant (TPC) & 1350 & 600 & 15 & Year \\
\hline Power Plant Lifespan (PL) & 20 & 20 & 20 & $\%$ \\
\hline Discount rate (R) & 20 & 20 & 6.7 & $\%$ \\
\hline Depreciation rate (DR) & 5 & 5 & & \\
\hline
\end{tabular}

\section{Results and Discussion}

In the following, the results of calculations and data above have been calculated and presented to determine the levelized cost of fuel for power plants based on rial and dollar prices in two types of gas and diesel fuels, along with environmental pollutants[25].

Major wind farms require dollar resources in the initial investment sector, which is also considered in dollars in the current model. In gas power plants, the main sources of cost are during the power plant operation, and the fuel of the power plant has a significant share in it. The key point in this section is the opportunity cost of fuel or the value of its export or import, and therefore we have considered fuel calculations based on dollar costs. Although the wind farm economics evaluation has been done in the current situation, the sensitivity analysis shows that this plan will remain economical even in higher fuel prices. The increase in the fuel price has effects on all sectors of the economy and general inflation, but given that in the study of wind and gas power plants, we have considered more than $80 \%$ of costs, including wind power plant equipment and gas power plant in foreign currency, the effect of the rate increase Currency on general inflation does not change much in our calculations. 
Table 3. Levelized cost of gas power plant and wind power plant

\begin{tabular}{|c|c|c|c|}
\hline \multirow[t]{2}{*}{ Fuel cost } & \multicolumn{2}{|c|}{$\mathrm{LCOE}_{w}(\$ / \mathbf{k W h})$} & $\mathrm{LCOE}_{t}(\$ / \mathbf{k W h})$ \\
\hline & Wind 2MW & Wind $660 \mathrm{~kW}$ & Gas \\
\hline Subsidies $\left(3\right.$ cents $/ \mathrm{m}^{3}$ ) & 0.083 & 0.083 & 0.078 \\
\hline 15 cents $/ \mathrm{m}^{3}$ & 0.083 & 0.083 & 0.317 \\
\hline 30 cents $/ \mathrm{m}^{3}$ & 0.1 & 0.099 & 0.556 \\
\hline 45 cents $/ \mathrm{m}^{3}$ & 0.117 & 0.115 & 0.795 \\
\hline 60 cents $/ \mathrm{m}^{3}$ & 0.134 & 0.131 & 1.034 \\
\hline 75 cents $/ \mathrm{m}^{3}$ & 0.1 & 0.099 & 1.273 \\
\hline 90 cents $/ \mathrm{m}^{3}$ & 0.117 & 0.115 & 1.512 \\
\hline 105 cents $/ \mathrm{m}^{3}$ & 0.134 & 0.131 & 1.751 \\
\hline
\end{tabular}

According to the results, it can be seen that the liberalization of energy prices, especially the price of fuel used by power plants based on real energy prices, fully justifies the use of wind turbines. For further explanation, several figures obtained in this regard are presented. The figures are obtained from summation and sensitivity analysis.

Table 4. Levelized cost of Diesel power plant and wind power plant

\begin{tabular}{|c|c|c|c|}
\hline \multirow{2}{*}{ Fuel cost } & \multicolumn{2}{|c|}{ LCOE $_{\mathbf{w}} \mathbf{( \$ \mathbf { k W h } )}$} & LCOEt(\$/kWh) \\
\cline { 2 - 4 } & Wind 2MW & Wind 660kW & Diesel \\
\hline Subsidies (10 cents/liter) & 0.083 & 0.083 & 0.176 \\
\hline 30 cents/liter & 0.083 & 0.083 & 0.742 \\
\hline 50 cents/liter & 0.1 & 0.099 & 0.183 \\
\hline 70 cents/liter & 0.117 & 0.115 & 0.19 \\
\hline 90 cents/liter & 0.134 & 0.131 & 0.196 \\
\hline 110 cents/liter & 0.1 & 0.099 & 0.886 \\
\hline 130 cents/liter & 0.117 & 0.115 & 1.03 \\
\hline 150 cents/liter & 0.134 & 0.131 & 1.174 \\
\hline
\end{tabular}

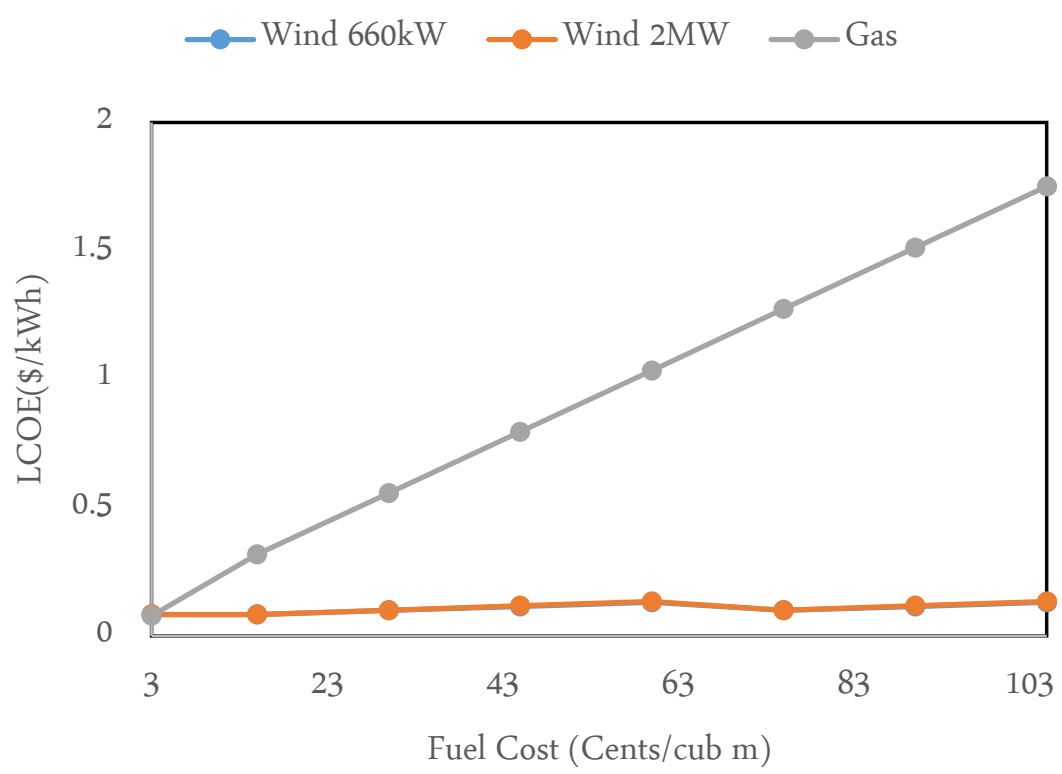

Figure 3. Comparison of the levelized cost of gas and wind power plants with the different prices of gas 


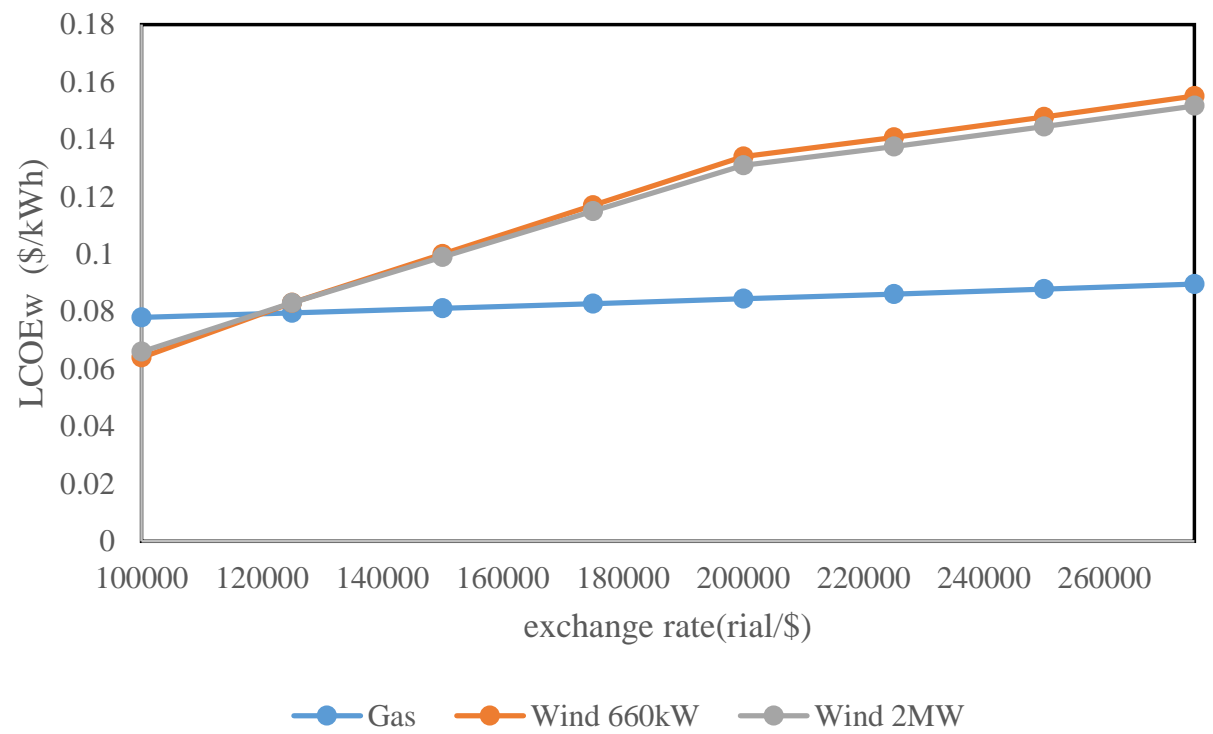

Figure 4. Comparison of the levelized cost of gas and wind power plants with the different exchange rate

According to Figure 4, it is clear that the fuel price of power plants at current prices and based on the use of gas will make gas power plants still more economical. This case shows that even the cost of pollution can not make the wind farm cost-effective, and this plant is very sensitive to fuel price changes and exchange rates due to the high cost of purchasing imported equipment[26-28].

According to Figure 3, if gas is used to fuel gas power plants, it is clear that wind power plants will be cost-effective in the real price of gas. The fuel of power plants (if the real conditions of the country are taken into account) will usually be replaced by diesel due to the higher consumption of gas in domestic applications in winter, if the share of this replacement is $30 \%$ per year, even at a price with high subsides the wind farms are feasible (up to an exchange rate of 175000 Rials/\$). This condition is shown in Figure 5.

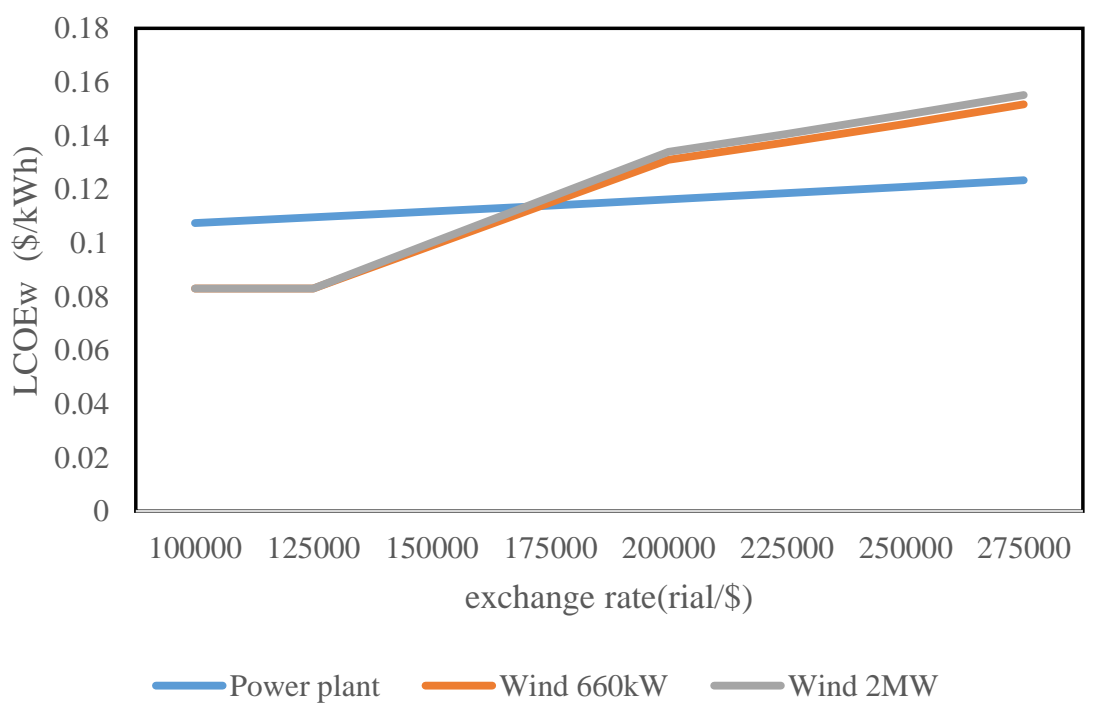

Figure 5. Comparison of the levelized cost of gas and wind power plants based on the combination of gas and diesel fuel consumption with the current price 
If the fuel consumption of power plants is calculated based on real prices, wind power plants will be justified in gas consumption as single fuel and gas and diesel consumption simultaneously. On the other hand, due to electricity generation costs using 660 $\mathrm{kW}$ and $2 \mathrm{MW}$ turbines, it is necessary to use $2 \mathrm{MW}$ turbines due to high efficiency and less land use, converting more energy from wind energy[29].

Considering that the distance of construction of wind turbines is related to the diameter of their rotor and with increasing capacity, the diameter of the rotor increases with a smaller ratio, so it can be concluded that wind turbines with higher capacity in the occupied space are equivalent to turbines with Less capacity produces more power. For example, according to the information of wind turbines on the website of the Danish company Vestas, the diameter of a $660 \mathrm{~kW}$ wind turbine rotor is 46 meters, the diameter of a $2 \mathrm{MW}$ wind turbine is 110 meters, and the diameter of $3.3 \mathrm{MW}$ turbine rotor is 117 meters. Therefore, a simple calculation shows that a 3.3 MW turbine does not increase the capacity by five times to a $660 \mathrm{~kW}$ turbine, while the rotor diameter is only 2.54 times, and for a $2 \mathrm{MW}$ wind turbine, it increases by 3.3 times compared to $660 \mathrm{~kW}$. At the same time, the rotor diameter has increased only 2.3 times[30-34].

Another reason for the advantage of large size wind turbines is their lower noise. In large wind turbines, although the intensity of the generated sound increases, less sound reaches the ground due to the higher height of the tower from the ground. For example, the sound intensity of a $660 \mathrm{~kW}$ wind turbine is 102 decibels, which is 48 decibels due to the average height of 50 meters of the tower. On the other hand, the sound intensity of the v90 wind turbine is $2 \mathrm{MW}$, equal to 104 decibels, which due to the average height of 90 meters of its tower, the sound intensity of 44 decibels can be heard on the ground [34-37].

According to Figures 3 and 4, the cost of one-kilowatt-hour of electricity in a wind farm is 8.3 cents (the cost is not much different in $660 \mathrm{~kW}$ and $2 \mathrm{MW}$ power plants), while in a gas plant, it is 31 cents and in a diesel power plant is 71 cents and with a combined gas and diesel fuel is 42 cents. Also, the sensitivity of cost to exchange rate in wind power plants is higher than gas and hybrid power plants.

\section{Conclusions}

Liberalization of energy prices, especially fuel prices of power plants based on real energy prices, fully justifies wind turbines. The fuel price of power plants at current prices and based on the use of gas will make gas power plants still more economical. However, if diesel is used to fuel gas power plants, it will be quite economical to use wind power plants due to the higher diesel price than gas. If the price of gas increases in Rials and gets closer to the Rial price of diesel, the gas-fired power plant will not compete with the wind power plant, and the cost of electricity generated will be very high. Also, if the price of currency increases, the economic efficiency of generating electricity in wind power plants will increase its distance from gas power plants, and gas power plants will produce more expensive electricity than wind power plants. Of course, among the two wind turbine technologies in question, 2-megawatt turbines will cost less than 660-megawatt turbines if the cost of the plant's land is taken into account; Although the cost difference between the two technologies is slightly different. Both are less than the cost of generating electricity at a gas plant.

Based on the research, although the research hypotheses have been answered so far, according to the research findings, other causes can be mentioned that, because it is outside the scope of the research hypotheses, are presented as policy recommendations:

A) Due to eliminating energy subsidies in increasing the efficiency of power plants, the price of fuel received by power plants should be calculated freely, and electricity should be purchased at the real price. In this case, in terms of fuel cost in the cost price of electricity, this price increases, and as a result, due to the economic efficiency of wind power generation, an increase in the guaranteed purchase price of wind power is possible, and the field of wind power plants is provided. 
B) According to the research results, there is no significant difference between the cost of electricity generated in wind power plants with $660 \mathrm{~kW}$ and $2 \mathrm{MW}$ turbines. Therefore, it is suggested that due to the increase in capacity in MW power plants, higher level of technology, and less land required by the power plant in MW turbines, the use of MW turbines should be given priority. On the other hand, due to the equal-cost of these two types of technology, the possibility of generating electricity is limited if a wind farm is covered with low-power turbines; Therefore, it is necessary to use high-power megawatt turbines in the construction of wind farms.

C) Increasing the exchange rate on increasing the construction cost of wind farms, localization of the wind turbine industry focusing on imported components should be prioritized. This localization will also help the employment of specialized forces in the country.

Supplementary Materials: "Data will be available by an official request from the corresponding author."

Author Contributions: "Conceptualization, SMYM and NN; methodology, SMYM; software, NN; validation, $\mathrm{XX}, \mathrm{YY}$ and $\mathrm{ZZ}$; formal analysis, $\mathrm{XX}$; investigation, $\mathrm{XX}$; resources, $\mathrm{XX}$; data curation, $\mathrm{XX}$; writing - original draft preparation, ZBJ; writing-review and editing, ZBJ; visualization, NN; supervision, NN; project administration, NN; funding acquisition, NN, All authors have read and agreed to the published version of the manuscript."

Funding: "This research received no external funding."

Data Availability Statement: “Data will be available by an official request from the corresponding author."

Acknowledgments: “No Specific support was used."

Conflicts of Interest: “The authors declare no conflict of interest."

\section{References}

[1] Kabir, E.; Kumar, P.; Kumar, S.; Adelodun, A.A.; Kim, K.-H. Solar energy: Potential and future prospects. Renew. Sustain. Energy Rev. 2018, 82, 894-900.

[2] Lee, C.-Y.; Ahn, J. Stochastic modeling of the levelized cost of electricity for solar PV. Energies 2020, 13, 3017.

[3] Ko, J.-S.; Huh, J.-H.; Kim, J.-C. Overview of maximum power point tracking methods for PV system in micro grid. Electronics $2020,9,816$.

[4] Gholami, H.; Røstvik, H.N.; Müller-Eie, D. Holistic economic analysis of building integrated photovoltaics (BIPV) system: Case studies evaluation. Energy Build. 2019, 203, 109461.

[5] Gholami, H.; Røstvik, H.N. Economic analysis of BIPV systems as a building envelope material for building skins in Europe. Energy 2020, 204, 117931.

[6] Gholami, H.; Nils Røstvik, H.; Manoj Kumar, N.; Chopra, S.S. Lifecycle cost analysis (LCCA) of tailor-made building integrated photovoltaics (BIPV) façade: Solsmaragden case study in Norway. Solar Energy 2020, 211, 488-502.

[7] Gholami, H.; Nils Røstvik, H. The effect of climate on the solar radiation components on building skins and building integrated photovoltaics (BIPV) materials. Energies 2021, 14, 1847.

[8] Esmailian, E.; Gholami, H.; Røstvik, H.N.; Menhaj, M.B. A novel method for optimal performance of ships by simultaneous optimisation of hull-propulsion-BIPV systems. Energy Convers. Manag. 2019, 197, 111879.

[9] Daly, H.; Walton, M. World Energy Outlook 2017. 2017. Available online: https://www.iea.org/reports/world-energy-outlook2017 (accessed on 1 March 2021).

[10] International Renewable Energy Agency. Renewable Energy in Cities; International Renewable Agency: Abu Dhabi, United Arab Emirates, 2016.

[11] Gholami, H.; Røstvik, H.N.; Müller-Eie, D. Analysis of solar radiation components on building skins for selected cities. In Proceedings of the 14th Conference on Advanced Building Skins, Bern, Switzerland, 28-29 October 2019; Advanced Building Skins (ABS): Bern, Switzerland, 2019; pp. 541-549.

[12] Steemers, K. Energy and the city: Density, buildings and transport. Energy Build. 2003, 35, 3-14.

[13] Villa-Arrieta, M.; Sumper, A. Economic evaluation of nearly zero energy cities. Appl. Energy 2019, 237, 404-416.

[14] Parag, Y.; Sovacool, B.K. Electricity market design for the prosumer era. Nat. Energy 2016, 1, 1-6.

[15] Aldersey-Williams, J.; Rubert, T. Levelised cost of energy -A theoretical justification and critical assessment. Energy Policy $2019,124,169-179$. 
[16] Shen, W.; Chen, X.; Qiu, J.; Hayward, J.A.; Sayeef, S.; Osman, P.; Meng, K.; Dong, Z.Y. A comprehensive review of variable renewable energy levelized cost of electricity. Renew. Sustain. Energy Rev. 2020, 133, 110301.

[17] Reichelstein, S.; Sahoo, A. Time of day pricing and the levelized cost of intermittent power generation. Energy Econ. 2015, 48, 97-108.

[18] Varro, L.; Ha, J. Projected Costs of Generating Electricity - 2015 Edition; Nuclear Energy Agency (NEA): Paris, France, 2015.

[19] Mohammadi, F.; Gholami, H.; Gharehpetian, G.B.; Hosseinian, S.H. Allocation of centralized energy storage system and its effect on daily grid energy generation cost. IEEE Trans. Power Syst. 2017, 32, 2406-2416.

[20] Nissen, U.; Harfst, N. Shortcomings of the traditional "levelized cost of energy" [LCOE] for the determination of grid parity. Energy 2019, 171, 1009-1016.

[21] Górnowicz, R.; Castro, R. Optimal design and economic analysis of a PV system operating under Net Metering or Feed-InTariff support mechanisms: A case study in Poland. Sustain. Energy Technol. Assess. 2020, 42, 100863.

[22] Castaneda, M.; Zapata, S.; Cherni, J.; Aristizabal, A.J.; Dyner, I. The long-term effects of cautious feed-in tariff reductions on photovoltaic generation in the UK residential sector. Renew. Energy 2020, 155, 1432-1443.

[23] Cui, Y.; Zhu, J.; Meng, F.; Zoras, S.; McKechnie, J.; Chu, J. Energy assessment and economic sensitivity analysis of a gridconnected photovoltaic system. Renew. Energy 2020, 150, 101-115.

[24] De Oliveira Pinto Coelho, E.; Aquila, G.; Bonatto, B.D.; Balestrassi, P.P.; de Oliveira Pamplona, E.; Nakamura, W.T. Regulatory impact of photovoltaic prosumer policies in Brazil based on a financial risk analysis. Utilit. Policy 2021, 70, 101214.

[25] Mundada, A.S.; Shah, K.K.; Pearce, J.M. Levelized cost of electricity for solar photovoltaic, battery and cogen hybrid systems. Renew. Sustain. Energy Rev. 2016, 57, 692-703.

[26] Limmanee, A.; Songtrai, S.; Udomdachanut, N.; Kaewniyompanit, S.; Sato, Y.; Nakaishi, M.; Kittisontirak, S.; Sriprapha, K.; Sakamoto, Y. Degradation analysis of photovoltaic modules under tropical climatic conditions and its impacts on LCOE. Renew. Energy 2017, 102, 199-204.

[27] Komilov, A. Location and orientation based LCOE: Simplified visual analysis and generalization of the levelized cost of electricity from storageless photovoltaic systems. Int. J. Energy Res. 2020, 45, 5649-5658.

[28] Talavera, D.L.; Muñoz-Cerón, E.; Ferrer-Rodríguez, J.P.; Pérez-Higueras, P.J. Assessment of cost-competitiveness and profitability of fixed and tracking photovoltaic systems: The case of five specific sites. Renew. Energy 2019, 134, 902-913.

[29] Patel, M.T.; Asadpour, R.; Woodhouse, M.; Deline, C.; Alam, M.A. LCOE*: Re-thinking LCOE for photovoltaic systems. In Proceedings of the 2019 IEEE 46th Photovoltaic Specialists Conference (PVSC), Chicago, IL, USA, 16-21 June 2019; pp. 17111713.

[30] Sinaga, R.; Tuati, N.F.; Beily, M.D.; Sampeallo, A.S. Modeling and analysis of the solar photovoltaic levelized cost of electricity (LCoE)-case study in Kupang. J. Phys. Conf. Ser. 2019, 1364, 012066.

[31] World Bank Group. Electric Power Transmission and Distribution Losses (\% of Output). Available online: https://data. worldbank.org/indicator/EG.ELC.LOSS.ZS?locations=BR (accessed on 1 March 2021).

[32] Moro, A.; Lonza, L. Electricity carbon intensity in European Member States: Impacts on GHG emissions of electric vehicles. Trans. Res. Part D Trans. Environ. 2018, 64, 5-14.

[33] Eurostat. Electricity Price Statistics. Available online: https://ec.europa.eu/eurostat/statistics-explained/index.php/Electricity_ price_statistics\#Electricity_prices_for_household_consumers (accessed on 1 March 2021).

[34] Jordan, D.C.; Kurtz, S.R. Photovoltaic degradation rates-an analytical review. Prog. Photovolt. Res. Applicat. 2013, 21, 1229.

[35] Photovoltaic Geographical Information System (PVGIS). Overview of PVGIS Data Sources and Calculation Methods. Available online: https://ec.europa.eu/jrc/en/PVGIS/docs/methods (accessed on 1 March 2021).

[36] Acciari, G.; Adamo, G.; Ala, G.; Busacca, A.; Caruso, M.; Giglia, G.; Imburgia, A.; Livreri, P.; Miceli, R.; Parisi, A.; et al. Experimental investigation on the performances of innovative PV vertical structures. Photonics 2019, 6, 86.

[37] Evola, G.; Margani, G. Renovation of apartment blocks with BIPV: Energy and economic evaluation in temperate climate. Energy Build. 2016, 130, 794-810. 